\title{
Karakteristik Fenotip dan Genotip Gen GH (Growth Hormon) pada Ayam Tolaki
}

\author{
Muhammad Amrullah Pagala1*, Achmad Selamet Aku', Rusli Badaruddin', Hamdan Has ${ }^{1}$ \\ ${ }^{1}$ Fakultas Peternakan Universitas Halu Oleo, J1 HEA Mokodompit Kampus Hijau \\ Bumi Tridharma, Anduonohu, Kendari 93232 \\ *Email korespondensi: amroe74@gmail.com
}

(Diterima: 10-7-2018; disetujui 25-8-2018)

\begin{abstract}
ABSTRAK
Penelitian ini bertujuan meningkatkan mutu genetik ayam lokal melalui pendekatan genetik dan karakterisasi fenotip untuk keperluan seleksi. Gen cGH (Chicken Growth Hormon) merupakan salah satu gen yang bertanggungjawab terhadap sifat pertumbuhan ayam lokal. Ayam tolaki adalah ayam lokal yang berasal dari Sulawesi Tenggara. Penelitian ini menggunakan metode fenotyping sifat produksi dan genotyping dengan Teknik PCR. Sebanyak 50 tetua ayam tolaki dipelihara 4 minggu. Hasil Penelitian menunjukkan Rataan bobot badan ayam tolaki berkisar antara $1.395 \mathrm{~kg}-1.910 \mathrm{~kg}$, Rataan pertambahan bobot badan sebesar 58,78 (g/ekor/minggu), konsumsi ransum sebesar 81,37 (g/ekor/hari) dan konversi ransum 9,68. Pertambahan bobot badan pada jantan sedikit lebih tinggi $(60,30 \mathrm{~g} / \mathrm{ekor} / \mathrm{mg})$ dibandingkan dengan betina $(58,42 \mathrm{~g} / \mathrm{ekor} / \mathrm{mg})$. Pada penelitian ini berhasil diidentifikasi keberadaan gen cGH ayam tolaki melalui ekstraksi DNA dan amplifikasi melalui mesin PCR dengan panjang Ruas DNA sebesar 399 bp.
\end{abstract}

Kata kunci: gen cGH, ayam Tolaki, PCR, fenotipe

\begin{abstract}
This study aims to improve the genetic quality of local chickens through genetic approaches and phenotypic characterization for selection purposes. The cGH gene (Chicken Growth Hormone) is one of the genes responsible for local chicken growth traits. Tolaki chicken is a local chicken from Southeast Sulawesi. This study uses the phenotyping method of production and genotyping traits with PCR technique. A total of 50 parents of tolaki chicken were kept 4 weeks. The results showed average body weight of tolaki chicken ranged from $1,395 \mathrm{~kg}-1,910 \mathrm{~kg}$, average body weight gain was $58,78(\mathrm{~g} / \mathrm{head} /$ week), feed consumption was 81,37 (g/ head / day) and ration conversion 9,68. Body weight gain in males was slightly higher $(60.30 \mathrm{~g} / \mathrm{head} / \mathrm{mg})$ compared to females $(58.42 \mathrm{~g} / \mathrm{head} / \mathrm{mg})$. In this study, the presence of the tolaki chicken $\mathrm{cGH}$ gene was identified through DNA extraction and amplification through a PCR machine with a length of DNA section of $399 \mathrm{bp}$.
\end{abstract}

Keywords: Gracinia cowa, flavonoid, proximate analysis, inhibition

\section{PENDAHULUAN}

Kendala yang dihadapi saat ini adalah masih terbatasnya upaya yang serius dan kontinyu untuk memanfaatkan ayam lokal sebagai bahan baku genetik guna membentuk galur ayam unggul, padahal ayam lokal memiliki potensi genetik yang bernilai ekonomis tinggi seperti produksi daging dan telur, kemampuan bertahan terhadap iklim tropis yang lebih panas, serta daya tahan terhadap penyakit viral (Pagala et al, 2013;Pagala et al, 2017). Pemanfaatan ayam lokal di Indonesia sampai saat ini masih dalam taraf budidaya, ayam hanya digunakan sebagai final stock penghasil daging dan telur,

Ayam tolaki merupakan rumpun ayam lokal asal Sulawesi Tenggara. Sebagaimana yang dinyatakan (Pagala dan Nafiu, 2012), bahwa ayam ini berasal dari Sulawesi Tenggara, memiliki pola warna bulu yang mirip dengan ayam hutan merah (Gallus-gallus), sehingga ada yang menyebutnya sebagai ayam hutan. Performans ayam tolaki secara fisik memiliki postur tubuh yang relatif 
lebih kecil dan bentuk tubuh yang lebih ramping dibanding ayam kampung, dengan rata-rata berat Jantan $1.60 \pm 0.29 \mathrm{~kg}$ kisaran $(1.22-1.99 \mathrm{~kg})$ dan betina Rata-rata dengan berat $1.29 \pm 0.21 \mathrm{~kg}$, kisaran $(0.97-2.04 \mathrm{~kg})$. Lebih lanjut disebutkan sampai saat ini ayam tolaki masih dikelompokkan sebagai ayam aduan, sementara dengan postur tubuh ayam tolaki sebenarnya dapat diarahkan untuk tujuan produksi telur dan daging.

Salah satu kriteria produktivitas pada ternak adalah pertumbuhan. Pertumbuhan pada ternak dipengaruhi oleh faktor genetik dan lingkungan. Secara genetik pertumbuhan dikendalikan oleh sejumlah gen. Salah satu diantaranya adalah family gen hormon pertumbuhan seperti : Insulinlike growth factor I (IGF-I), Growth Hormon Reseptor $(G H R)$ dan Hormon pertumbuhan $(G H)$. Hormon pertumbuhan atau Growth Hormon (GH) dan Growth Hormon Receptor (GHR) serta Insulin-like growth factor I (IGF-I) merupakan faktor kritis dalam regulasi proses metabolisme dan distribusi energi dan berhubungan dengan pertumbuhan dan perkembangan tubuh ternak (Ip et al,2001; Zhou et al. 2005). Beberapa riset melaporkan hormon pertumbuhan GH berpengaruh terhadap pertumbuhan dan metabolisme melalui interaksi dengan spesifik receptor pada permukaan sel target. Sejumlah hasil penelitian menunjukkan beberapa genotipe dari gen GH dan GHR berpengaruh nyata terhadap terhadap pertumbuhan dan kualitas karkas, PBB dan efisiensi pakan (Bingxue et al. 2003:Muin, 2009).

Seleksi secara konvensional membutuhkan waktu yang cukup panjang serta biaya yang begitu besar, oleh sebab itu seleksi dengan pendekatan molekuler merupakan alternatif yang tepat. Melalui identifikasi secara molekuler dapat ditemukan informasi gen-gen spesifik yang terlibat dalam pembentukan keragaman genetik ayam lokal, termasuk gen-gen yang bertanggungjawab terhadap resistensi penyakit serta pengendali sifat produksi pada ayam lokal sehingga dapat dijadikan sebagai gen penciri dalam proses seleksi (Marker Assosiated Selection)

Penelitian ini bertujuan meningkatkan mutu genetik ayam lokal melalui pendekatan genetik dan lingkungan sehingga diperoleh parameter genetik yang akurat berupa kriteria seleksi yang tepat dalam waktu yang cepat dengan biaya yang murah, salah satunya adalah diperolehnya genotipe ayam tolaki berbasis gen GH sehingga dapat lebih efisien dan efektif dalam melakukan program pemuliaan dan pengembangan bibit ayam lokal.

\section{MATERI DAN METODE}

\section{Fenotyping}

Sampel tetua Ayam tolaki yang terdiri dari 50 ekor betina dan 10 ekor pejantan (umur \pm 7 bulan) dipelihara selama 4 minggu untuk menghasilkan telur tetas. Selanjutnya dari telur tetas tersebut dihasilkan Day Old Chicken (DOC) yang dipelihara selama 14 minggu.Tetua ayam tolaki dan DOC yang dihasilkan selanjutnya dilakukan fenotyping untuk mendapatkan koleksi data dan informasi sifat produksi pada ternak ayam melalui pengukuran dan pencatatan langsung sifat fenotip yang berhubungan dengan sifat produksi seperti pertambahan bobot badan mingguan, konsumsi pakan, konversi dan mortalitas.

\section{Genotyping}

Anakan ayam tolaki diambil sampel darahnya dan sampel bulunya untuk ekstraksi DNA. Ekstraksi DNA dari sampel bulu menggunakan kit ektraksi Phire Animal Tissue Direct PCR Kit (Thermo Fisher Scientific Inc.), sedangkan melalui sampel darah menggunakan metode phenol-chloroform (Sambrook et al. 1989). DNA yang telah diekstraksi di amplifikasi dengan mesin PCR. Produk PCR dipisahkan dengan metode elektroforesis gel poliakrilamida $5 \%$. Selanjutnya divisualisasikan dengan metode pewarnaan sensitif perak menurut Sulandari dan Zein (2003).

\section{HASIL DAN PEMBAHASAN}

\section{Karakteristik Fenotipik Ayam Tolaki}

Data fenotyping ayam tolaki meliputi PBB, konsumsi kansum, konversi ransum selama 4 minggu disajikan pada Tabel 1.

Tabel 1. Rataan PBB, konsumsi ransum, dan konversi ransum ayam tolaki

\begin{tabular}{clccc}
\hline No & $\begin{array}{c}\text { Waktu } \\
\text { Pemeliha } \\
\text { raan }\end{array}$ & $\begin{array}{c}\text { PBB } \\
\text { (g/ekor/ } \\
\text { mg) }\end{array}$ & $\begin{array}{c}\text { Konsumsi } \\
\text { Ransum } \\
\text { (g/ekor/ } \\
\text { mg) }\end{array}$ & $\begin{array}{c}\text { Konversi } \\
\text { Ransum }\end{array}$ \\
\hline 1 & Minggu 1 & 57,54 & 540,48 & 9,39 \\
2 & Minggu 2 & 58,56 & 577,74 & 9,86 \\
3 & Minggu 3 & 59,88 & 581,17 & 9,70 \\
4 & Minggu 4 & 59,14 & 579,00 & 9,79 \\
\hline & Total & 235,12 & 2278,39 & 38.75 \\
& Rataan & 58,78 & 569,59 & 9,68 \\
\hline
\end{tabular}

Berdasarkan data fenotyping tetua ayam tolaki dari Tabel $1 \mathrm{di}$ atas menunjukkan rata-rata 
PBB mingguan tetua ayam tolaki berkisar 58,78 (g/ekor/minggu), rata-rata konsumsi ransum 569,59 (g/ekor/minggu), dan rata-rata konversi ransum berkisar 9,68.

Capain rata-rata bobot badan diperoleh berkisar antara $1.395 \mathrm{~kg}-1.910 \mathrm{~kg}$. Hasil ini tidak jauh berbeda dengan penelitian yang telah dilakukan sebelumnya oleh Pagala dan Nafiu (2012) yang melaporkan rataan bobot badan ayam tolaki dengan rata-rata berat jantan $1.60 \pm 0.29 \mathrm{~kg}$ kisaran $(1.22-1.99 \mathrm{~kg})$ dan betina rata-rata dengan berat $1.29 \pm 0.21 \mathrm{~kg}$, kisaran $(0.97-2.04 \mathrm{~kg})$. Konsumsi ransum sebesar 572,02 (g/ekor/minggu) atau 81,72 (g/ekor/hari), sedikit dibawah konsumsi ayam kampung pada umumnya yang berkisar antara $90 \mathrm{~kg}-100 \mathrm{~kg}$. Hal ini dapat dimaklumi pada ayam tolaki ukuran tubuh yang lebih kecil berkorelasi dengan kapasitas asupan pakan jika dibandingkan dengan ayam kampung dengan ukuran tubuh yang lebih besar.

Konversi ransum 9,68 pada ayam tolaki mencerminkan angka yang sedikit lebih tinggi daripada konversi ransum umumnya pada ayam lokal yang mencapai 6 atau 7 pada pemeliharaan yang intensif. Hal ini disebabkan beberapa faktor, yakni (1) materi penelitian ini menggunakan generasi tetua ayam tolaki berupa indukan dan pejantan yang relatif tidak terlalu banyak mengalami pertumbuhan lagi. (2) ayam tolaki dalam penelitian ini didatangkan dari habitat aslinya di daerah pemukiman masyarakat yang berbatasan langsung dengan hutan. Proses adaptasi dari pemeliharaan ekstensif di alam terbuka ke pemeliharaan secara intensif berpengaruh terhadap pola makan dan tingkah laku ayam dan membutuhkan waktu adaptasi ayam yang cukup. Tingkah laku ayam tolaki amat lincah dan memiliki sifat agresivitas yang tinggi. Ayam Tolaki ini mampu bertahan hidup, bereproduksi dan menampilkan produksi yang cukup baik meskipun dalam kondisi lingkungan yang ekstrim di alam liar. Kemampuan ini berhubungan erat dengan daya adaptasi yang dimilikinya. Daya adaptasi pada ayam tolaki juga berkorelasi dengan sifat ketahanan terhadap penyakit.

\section{Fenotip Ayam Tolaki berdasarkan Jenis Kelamin}

Rataan data konsumsi pakan, PBB harian, konversi ransum dan daya hidup ayam tolaki jantan dan betina disajikan pada Tabel 2 . Berdasarkan data dari Tabel 2. diperoleh hasil konsumsi pakan yang tidak jauh berbeda antara ayam tolaki jantan dan betina yang berkisar antara 566,74 - 598,35 g/ekor/minggu,

Tabel 2. Rataan konsumsi pakan, PBB, konversi ransum dan daya hidup ayam tolaki berdasarkan jenis kelamin

\begin{tabular}{lcc}
\hline \multirow{2}{*}{ Parameter } & \multicolumn{2}{c}{ Jenis Kelamin } \\
\cline { 2 - 3 } Komsumsi & Jantan (5) & Betina (25) \\
\hline g/ekor/Mg) & $598,35 \pm 3,60$ & $566,74 \pm 2,38$ \\
PBB(g/ekor/mg) & $60.30 \pm 3,34$ & $58,42 \pm 2,36$ \\
Konversi Ransum & $9,92 \pm 1,04$ & $9,70 \pm 2,23$ \\
Daya Hidup (\%) & 100 & 100 \\
\hline
\end{tabular}

atau 80,96 - 85,47 g/ekor/hari. Rataan konsumsi ini berada sedikit dibawah kisaran konsumsi ayam lokal atau ayam Kampung pada umumnya yakni berkisar $90-100 \mathrm{~g} / \mathrm{ekor} / \mathrm{hari}$. Berdasarkan rataan pertambahan bobot badan, terlihat pada jantan lebih tinggi daripada ayam betina Perbedaan dalam pertambahan bobot badannya ini berpengaruh terhadap konversi yang dihasilkan. Fakta ini dapat dipahami sebab umumnya pada induk ayam tolaki sebagian besar energi yang diperoleh dikonversi kepada produksi telur, sedangkan pada ayam tolaki jantan energi yang diperoleh dikonversikan kepada pertambahan bobot tubuhnya. Oleh karena itu didapatkan pertambahan bobot yang rendah pada induk namun tidak sampai mempengaruhi daya hidup induk. Dalam penelitian ini diperoleh daya hidup induk dan ayam tolaki jantan mencapai $100 \%$. Daya hidup ini berkorelasi dengan pemberian vaksin ND dan AI yang sebelumnya terjadwal dan rutin dilakukan.

\section{Gen cGH pada Ayam Tolaki \\ Ekstraksi DNA \& Amplifikasi PCR}

Hasil ekstraksi DNA ayam tolaki yang dilanjutkan dengan proses perbanyakan (amplifikasi DNA) dengan PCR (Polymerisasi Chain Reaction) ditampilkan pada Gambar 1 di bawah ini.

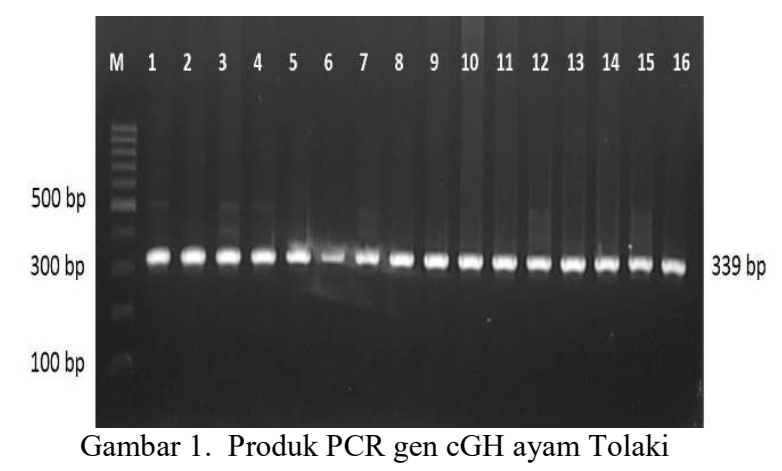

Berdasarkan hasil amplifikasi PCR DNA pada sampel darah ayam tolaki diperoleh 
informasi bahwa semua sampel ayam tolaki memiliki gen cGH dengan ukuran pita DNA sebesar 399 bp. Gen cGH adalah gen yang bertanggungjawab terhadap pertumbuhan, kemampuan produksi dan respon imun (Ip et al, 2001; Ge, et al, 2003). Ukuran pita DNA gen cGH pada ayam tolaki sebesar $399 \mathrm{bp}$. Hal ini menunjukkan gen cGH pada ayam tolaki lebih spesifik atau berbeda dibandingkan ayam lokal lainnya.

\section{KESIMPULAN}

Rataan bobot badan ayam tolaki berkisar antara $1,395 \mathrm{~kg}-1,910 \mathrm{~kg}$, lebih rendah daripada ayam kampung. Pemeliharaan selama 4 minggu diperoleh konsumsi ransum sebesar 569,59 g/ekor/minggu dan konversi ransum 9,11. PBB dan konversi pada jantan relatif lebih tinggi daripada ayam betina dengan daya hidup relatif sama. Ruas DNA gen cGH pada ayam tolaki berhasil diidentifikasi dengan panjang ukuran sebesar 399 bp.

\section{DAFTAR PUSTAKA}

Bingxue Y, D. Xuemei, F. Jing, H. Aoxiang, Xi, W. Changxin, \& L. Ning. 2003. Single nucleotide polymorphism analysis in chicken growth hormone gene and its associations with growth and carcass traits. Chinese Science Bulletin 48(15): August 2003.

Ip S.C.Y., Ip, X. Zhang \& F.C. Leung. 2001. Genomic growth hormone gene polymorphism in native chinese chicken. Expe.Biol.Med. 226(6):458-462.

Muin M.A. 2009. Polimorfisme leu/val gen growth hormone dan efeknya pada ukuran tubuh pedet SIMPO. Jurnal Ilmu Peternakan 4(1):24-31.

Pagala M.A, T. Saili, L.O. Nafiu, N. Sandiah, L.O. Baa, A.S. Aku, D. Zulkarnaen, \& W. Kurniawan. 2017. Polymorphism of $\mathrm{Mx} \mid$ Hpy81 genes in native chickens observed using the PCR-RFLP Technique. Int. J. Poult. Sci. 16(9):364368.

Pagala, M.A., A.M. Tasse, \& N. Ulupi. 2015. Association of cGH EcoRV gene with production in tolaki chicken. International Journal of Sciences: Basic and Applied Research 24(7):88-95.
Pagala, M.A., Muladno, C. Sumantri \& S. Murtini. 2013. Association of Mx gene genotype with antiviral and production traits in tolaki chicken. Journal of Poultry Science 12(12):735-739.

Pagala M.A. \& L.O. Nafiu. 2012. Identifikasi molekuler sifat anti viral ayam tolaki melalui deteksi gen Mx sebagai marka genetik. Agriplus 23:139-144.

Sambrook J., F. Fritsch, \& T. Maniatis. 1989. Molecular Cloning. A Laboratory Manual $2^{\text {nd }}$ ed. (US): Cold Spring Harbor Laboratory Press.

Sulandari S. \& M.S.A. Zein. 2003. Panduan Praktis Laboratorium DNA. Edisi Pertama. Bidang Zoologi, Pusat Penelitian Biologi. Lembaga Ilmu Pengetahuan Indonesia. Bogor.

Zhou H., A.D. Mitchell, J.P. McMurtry, C.M. Ashwell, \& S.J. Lamont. 2005. Insulinlike growth factor-I gene polymorphism associations with growth, body composition, skeleton integrity, and metabolic traits in chickens. Poultry Science 84:212-219 